\title{
$\mathrm{COSCi}_{\text {ech }}$ Jurnal Computer Science and Information Technology (CoSciTech)
}

\section{Analisa tanggapan terhadap PSBB di indonesia dengan algoritma decision tree pada twitter}

\author{
Aditya Quantano Surbakti*1, Regiolina Hayami², Januar Al-Amien ${ }^{3}$ \\ Email: ${ }^{1} 150401081 @$ student.umri.ac.id, ${ }^{2}$ regiolinahayami@umri.ac.id, ${ }^{3}$ januaralamien@umri.ac.id \\ ${ }^{123}$ Teknik Informatika, Fakultas Ilmu Komputer, Universitas Muhammadiyah Riau \\ Diterima: 20 Oktober 2021 | Direvisi: -| Disetujui: 16 Desember 2021 \\ (C)2020 Program Studi Teknik Informatika Fakultas Ilmu Komputer, \\ Universitas Muhammadiyah Riau, Indonesia
}

\begin{abstract}
Abstrak (10pt, tebal, dan rata kiri kanan)
Tanggapan masyarakat terkadang sulit untuk disampaikan kepada pihak penanggung jawab secara langsung, hal tersebut mendorong masyarakat untuk menyampaikan tanggapan, kritik dan sejenisnya melalui media sosial, salah satunya media sosial yang popular saat ini adalah twitter. Kumpulan tanggapan atau tweet dari pengguna twitter mengenai efek PSBB salah satunya dapat dimanfaatkan menjadi sebuah analisis sentimen opini publik. Data mengenai efek PSBB didapatkan sebanyak 2439 tweet, kemudian diolah menggunakan teknik penambangan data (data mining), didalamnya terdapat proses Pengumpulan Data, Text Preprocessing, Klasifikasi. Kemudian diujikan kedalam tiga algoritma yang berbeda untuk dibandingkan, algoritma yang digunakan yaitu Decision Tree, Naïve Bayes Classifier dan K-Nearest Neighbors (K-NN) dengan tujuan menemukan akurasi terbaik. Hasil tertinggi dari penelitian ini adalah algoritma Decision Tree dengan nilai accuracy $84.78 \%$, precision $84.78 \%$ dan recall $100 \%$.
\end{abstract}

Kata kunci: twitter, analisis sentimen, decision tree

\section{Analysis of response to PSBB in indonesia with the decision tree algorithm on twitter}

\begin{abstract}
(10pt, italic, tebal, dan rata kiri kanan)
Community opinions are sometimes difficult to convey to the person in charge directly, it encourages people to express their opinions, criticisms and the like through social media, one of which is the popular social media today is Twitter. One collection of opinions or tweets from Twitter users about the PSBB effect one of which can be used as an analysis of public opinion sentiments. Data on the effects of PSBB were obtained as many as 2439 tweets, then processed using data mining techniques (data mining), in which there are processes of Collecting Data, text preprocessing and classification. Then it is tested into three different algorithms to be compared, the algorithm used is Decision Tree, Nä̈ve Bayes Classifier and K-Nearest Neighbors (K$N N$ ) with the aim of finding the best accuracy. The highest results from this study were the Decision Tree algorithm with an accuracy value of $84.78 \%$, precision $84.78 \%$ and recall $100 \%$.
\end{abstract}

Keywords: twitter, sentiment analysis, decision tree

\section{Pendahuluan}

Pada saat ini Indonesia dilanda oleh Corona Virus Disease 2019 (covid-19). Virus tersebut menginfeksi saluran pernapasan yang disebabkan oleh Severe Acute Respiratory Syndrome Virus Corona 2 (SARS-CoV-2), atau yang sering disebut virus Corona. Virus ini bisa menyebabkan gangguan ringan pada sistem pernapasan, infeksi paru-paru yang berat, hingga kematian. Di Indonesia sendiri pada tanggal 2 Maret 2020 sampai tanggal 23 Mei 2020 tercatat sudah ada 20.796 orang positif terjangkit virus ini..(Hanafi and Ferdiansyah, 2020) 
Selain memakan banyak korban, banyak aktivitas yang terhenti akibat PSBB, seperti banyak pekerja yang dipulangkan, dibatasi aktivitas, dan masih banyak lagi. Semua informasi atau berita tentang COVID-19 dan PSBB selalu terupdate di media berita surat kabar dan televisi, selain media surat kabar dan TV, media sosial juga turut serta memberikan informasi tentang COVID19 dan PSBB seperti Facebook, Instagram, Twitter, dll. Permasalahan yang terjadi pada penelitian ini adalah data yang terlalu banyak sehingga penulis tidak dapat membedakan secara cepat dan tepat opini positif atau negatif pengguna Twitter tentang PSBB. Oleh karena itu, perlu menganalisis sentimen di Twitter tentang PSBB.(Saputra et al., 2020)

Analisis Sentimen merupakan perpaduan dari data mining dan text mining, atau sebuah cara yang digunakan untuk mengolah berbagai opini yang diberikan oleh konsumen atau para pakar melalui berbagai media, mengenai sebuah produk, jasa ataupun sebuah instansi.(Romadloni, Santoso and Budilaksono, 2019) Dengan demikian data mining dapat digunakan sebagai analisis sentimen karena dapat mengolah data tweet dalam jumlah besar mengunakan Algoritma Decision Tree.

Algoritmna Decision Tree merupakan salah satu metode yang ada pada teknik klasifikasi dalam data mining. Metode decision tree ini untuk mengubah fakta yang sangat besar menjadi pohon keputusan yang merepresentasikan aturan. Pohon keputusan juga berguna untuk mengekplorasi data, menemukan hubungan tersembunyi antara sejumlah calon variabel input dengan sebuah variabel target.(Pangestu, 2020)

Dalam penelitian (Puspita and Widodo, 2021) dapat diketahui bahwa metode KNN, Decision Tree, dan Naïve Bayes dapat digunakan dalam bidang data mining. Analisis sentimen terhadap data Twitter mengenai layanan BPJS mencapai tingkat akurasi 96.01\%. Dimana class precision untuk pred. negative adalah $52.17 \%$, pred positive adalah $0.00 \%$, dan pred. neutral adalah 97.27\% dalam metode KNN. Lalu tingkat akurasi mencapai 96.13\%. Dimana class precision untuk pred. negative adalah 55.00\%, pred positive adalah $0.00 \%$, dan pred. neutral adalah $97.28 \%$ dalam metode Decision Tree. Dan yang terakhir mencapai akurasi 89.14\%. Dimana class precision untuk pred. negative adalah $16.67 \%$, pred positive adalah $1.64 \%$, dan pred. neutral adalah 98.40\% dengan metode Naïve Bayes.

Dalam penelitian ini, dapat diketahui bahwa metode Decision Tree adalah metode yang tingkat akurasinya lebih tinggi dibandingkan kedua metode lainnya dengan tingkat akurasi sebesar 96.13\%.(Puspita and Widodo, 2021)

\section{Metode Penelitian}

Dalam Penelitian ini menggunakan dataset untuk deteksi Tanggapan mengumpulkan data twit sebanyak 2439 tweet dalam bahasa Indonesia. Pada dataset terdapat 2 kolom yaitu Label dan Tweet. Pada Label dikelompokkan menjadi 2 yaitu Positif dan Negatif. Selain dataset tersebut, peneliti juga mengumpulkan data twit langsung dari Twitter menggunakan Twitter API untuk digabungkan dengan dataset tersebut. Sehingga dataset tersebut tetap update. Kerangka konseptual merupakan suatu bentuk kerangka berpikir yang dapat digunakan sebagai pendekatan dalam memecahkan masalah. Biasanya kerangka penelitian ini menggunakan pendekatan ilmiah dan memperlihatkan hubungan antar variabel dalam proses analisisnya.

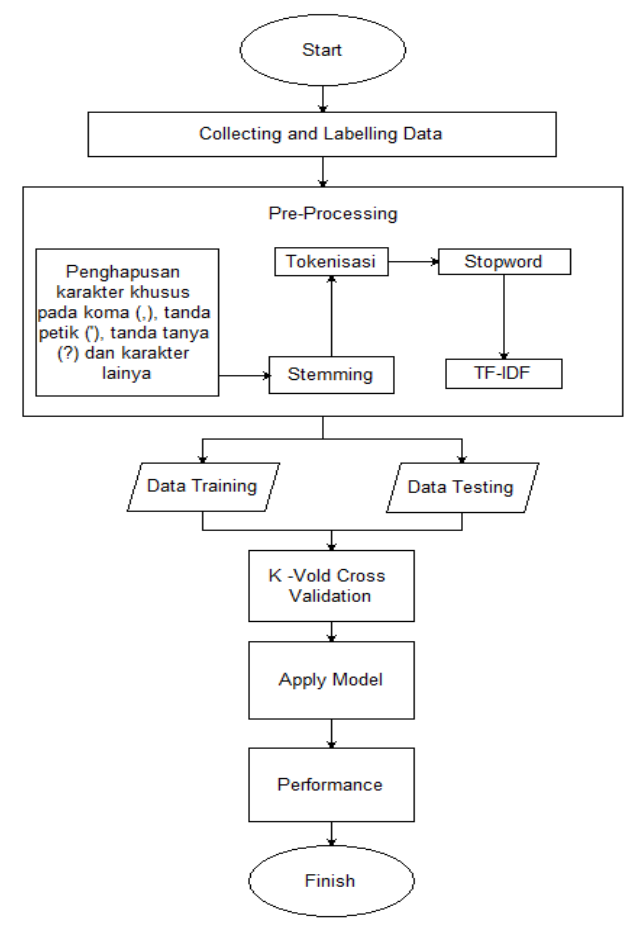

Gambar 1 Alur Penelitian 


\subsection{Hasil Pengumpulan Data}

Data yang digunakan pada penelitian ini bersumber dari postingan pada media sosial twitter. Proses pengambilan data twitter dengan menggunakan kata kunci \#PSBB dengan menggunakan Bahasa Indonesia dan data yang diambil sebanyak 2439 tweet. Data twitter diambil dengan menggunakan software Python ver. 3.9. Proses pelabelan data dilakukan secara manual dengan memberikan nilai positif atau negative terhadap sebuah postingan di twitter. Apabila sebuah kalimat mengandung rasa ketidaksukaan pada PSBB maka diberikan label negative dan sebaliknya jika tidak ada penolakan terhadap PSBB maka diberikan label positif.

\subsection{Organisasi Naskah}

Setelah proses pengumpulan data selanjutnya akan dilakukan preprocessing data. Preprocessing merupakan langkah untuk mengubah data mentah menjadi data atau format yang sesuai untuk tahap analisis berikutnya. Preprocessing meliputi penghapusan karakter khusus, stemming, stopword dan tokenisasi. Tujuan dilakukan preprocessing data adalah untuk menyaring data penting dari kumpulan data.

1. Penghapusan karakter khusus

Menghapus karakter-karakter khusus pada sebuah string atau kalimat misal koma (,), tanda petik ('), tanda tanya (?) dan karakter lainya.

2. Stemming

Stemming adalah proses membentuk suatu kata menjadi kata dasarnya. Proses ini berupa penghilangan semua imbuhan (affix) yang terdiri dari awalan (prefix), sisipan (infix), akhiran (suffix) dan duplikasi. Proses stemming dilakukan untuk mendapatkan kata dasar dari kata berimbuhan.

3. Tokenisasi

Tokenisasi adalah proses pemotongan seluruh urutan karakter menjadi satu potongan kata. Proses ini untuk membagi teks yang dapat berupa kalimat, paragraf atau dokumen, menjadi token-token.

4. Stopword

Stopword adalah kata umum (common words) yang biasanya muncul dalam jumlah besar dan dianggap tidak memiliki makna.

5. Weighting (Pembobotan)

TF-IDF adalah salah satu metode pembobotan sebuah kata didalam sistem pencarian informasi. TF-IDF metode yang menggambungkan Term Frequency (TF) dan Inverse Document Frequency (IDF). Term Frequency adalah kemunculuan frekuensi munculnya kata sama pada dokumen. Inverse Document Frequency banyaknya koleksi dokumen yang bersangkutan mengandung kata tertentu.

\subsection{K-fold Cross Validation}

Merupakan memiliki dua subproses : subproses Training dan subproses Testing. Subproses Training digunakan untuk melatih sebuah model. Model yang telah dilatih (diuji atau diproses terlebih dahulu) kemudian diterapkan dalam subproses Testing. Kinerja model akan diukur selama fase Testing.

\subsection{Apply Model}

Untuk menerapkan model yang telah dilatih sebelumnya menggunakan data training pada unlabeled data (data testing). Tujuannya adalah untuk mendapatkan prediksi pada unlabeled data (data testing) yang belum memiliki label. Yang perlu diperhatikan adalah data testing harus memiliki urutan, jenis, maupun peran atribut yang sama dengan data training.

\subsection{Performance}

Digunakan untuk mengevaluasi kinerja model yang memberikan daftar nilai kriteria kinerja secara otomatis sesuai dengan tugas yang diberikan. Misalkan untuk klasifikasi, kriteria yang diberikan adalah accuracy, precision dan recall.

\section{Hasil dan Pembahasan}

\subsection{Hasil Pengumpulan Data dan Labelling Data}

Data yang digunakan pada penelitian ini bersumber dari postingan pada media sosial twitter. Proses pengambilan data twitter dengan menggunakan kata kunci \#PSBB dengan menggunakan Bahasa Indonesia dan data yang diambil sebanyak 2439 tweet. Data twitter diambil dengan menggunakan software Python ver. 3.9. Proses pelabelan data dilakukan secara manual dengan memberikan nilai positif atau negative terhadap sebuah postingan di twitter. Apabila sebuah kalimat mengandung rasa ketidaksukaan pada PSBB maka diberikan label negative dan sebaliknya jika tidak ada penolakan terhadap PSBB maka diberikan label positif. 


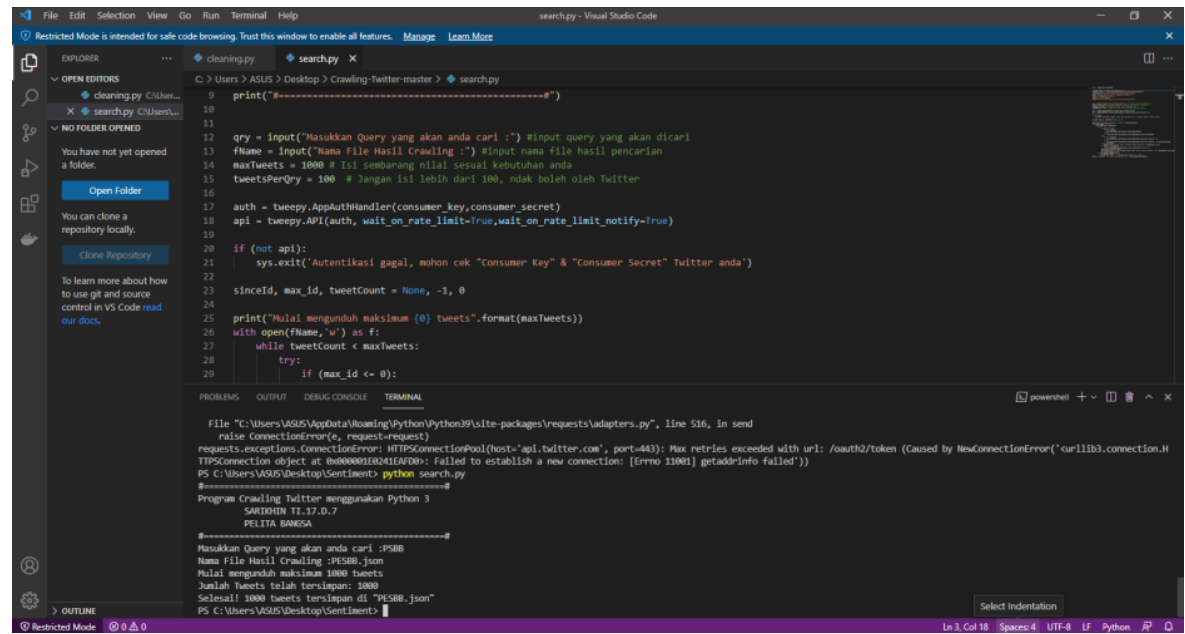

Hasil dari pengmpulan data sebagai berikut :

Gambar 2 Pengumpulan Data

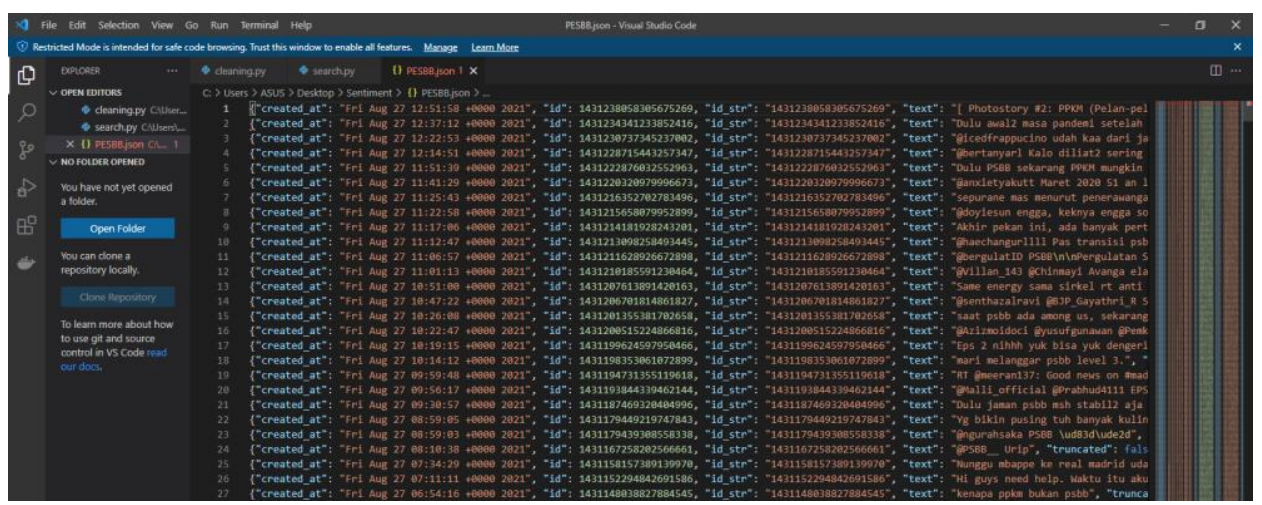

Gambar 3 Hasil Crawling Data

\subsection{Prepocessing}

Text Preprocessing merupakan tahap awal dalam sebuah penelitian terhadap kumpulan banyak teks yang telah dipersiapkan untuk menjadi sebuah data yang akan diolah lebih lanjut. Suatu teks tidak dapat diproses langsung oleh algoritma pencarian, oleh karena itu dibutuhkan preprocessing text untuk mengubah teks menjadi data numeric. Proses ini terdiri dari beberapa tahap pembersihan dokumen sebagai berikut :

1. Cleansing

Membersihkan Tweet yang tidak diperlukan untuk mengurangi noise. Penghilangkan karakter HTML, kata kunci, ikon emosi, hastag (\#), username, url (http://situs.com) ataupun e-mail, menghapus karakter-karakter khusus pada sebuah string atau kalimat misal koma (,), tanda petik ('), tanda tanya (?) dan karakter lainya.

\begin{tabular}{|c|c|}
\hline $\begin{array}{l}\text { @erkytwelve @muchhilalr19 } \\
\text { @AREAJULID Pemain PS... }\end{array}$ & $\begin{array}{r}\text { Pemain PSBB \&amp; merangkap jd } \\
\text { anak gawang ... }\end{array}$ \\
\hline $\begin{array}{r}\text { Lagi ngebayangin istilah PSBB, PPKM } \\
\text { masuk ke m... }\end{array}$ & $\begin{array}{r}\text { Lagi ngebayangin istilah PSBB, } \\
\text { PPKM masuk ke m... }\end{array}$ \\
\hline $\begin{array}{r}\text { psbb diperpanjangnya per } 2 \text { minggu, } \\
\text { skrng ppkm d... }\end{array}$ & $\begin{array}{r}\text { psbb diperpanjangnya per } 2 \text { minggu, } \\
\text { skmg ppkm d... }\end{array}$ \\
\hline $\begin{array}{l}\text { Selamat tahun baru islam } v \text { 'n } 1 \text { muharram } \\
\qquad 1443 \mathrm{HL} . \text {. }\end{array}$ & $\begin{array}{l}\text { Selamat tahun baru islamirin } 1 \\
\text { muharram } 1443 \mathrm{HL} . .\end{array}$ \\
\hline $\begin{array}{r}@ \text { AREAJULID inget dlu awal psbb sepi } \\
\text { bgt }\end{array}$ & inget dlu awal psbb sepi bgt \\
\hline$\ldots$ & ... \\
\hline $\begin{array}{l}\text { Karena emang aku cuma di rumah } \\
\text { doang, keluar k... }\end{array}$ & $\begin{array}{r}\text { Karena emang aku cuma di rumah } \\
\text { doang, keluar } \mathrm{k} . . .\end{array}$ \\
\hline @michaelyuan_durung meneh psbb... & durung meneh psbb... \\
\hline $\begin{array}{r}\text { Ngga. Gue ga bosen berbulan2 di } \\
\text { rumah. Gue ga } \ldots . .\end{array}$ & $\begin{array}{r}\text { Ngga. Gue ga bosen berbulan2 di } \\
\text { rumah. Gue ga ... }\end{array}$ \\
\hline $\begin{array}{l}\text { @dewahoya pasar maling ga peduli } \\
\text { psbb ppkm, tu... }\end{array}$ & $\begin{array}{r}\text { pasar maling ga peduli psbb ppkm, } \\
\text { tutup e pas... }\end{array}$ \\
\hline $\begin{array}{r}\text { Dari awal psbb masyarakat dah punyaaa } \\
\text { trust is... }\end{array}$ & $\begin{array}{r}\text { Dari awal psbb masyarakat dah } \\
\text { punyaaa trust is... }\end{array}$ \\
\hline
\end{tabular}

Gambar 4 Hapus Karakter Khusus 
2. Stemming

Stemming adalah proses membentuk suatu kata menjadi kata dasarnya. Proses ini berupa penghilangan semua imbuhan (affix) yang terdiri dari awalan (prefix), sisipan (infix), akhiran (suffix) dan duplikasi. Proses stemming dilakukan untuk mendapatkan kata dasar dari kata berimbuhan.

\begin{tabular}{|c|c|}
\hline text & Tweet_Clean \\
\hline $\begin{array}{l}\text { e @muchhilalr } 19 \\
\text { ID Pemain PS. }\end{array}$ & $\begin{array}{r}\text { [main, psbb, rangkap. } \\
\text { gawan }\end{array}$ \\
\hline $\begin{array}{r}\text { Lagi ngebayangin istilah PSBB, PPKMM } \\
\text { masuk ke m. }\end{array}$ & $\begin{array}{r}\text { [ngebayangin, istilah, ps } \\
\text { mas: }\end{array}$ \\
\hline $\begin{array}{r}\text { psbb diperpanjangnya pe } \\
\text { skrng }\end{array}$ & $\begin{array}{r}\text { [psbb, panjang, mi } \\
\text { ppkm }\end{array}$ \\
\hline Selamat tahun baru islamirn 1 muhar & $\begin{array}{l}\text { [selamat, islam, } \\
\text { malar }\end{array}$ \\
\hline $\begin{array}{l}\text { @AREAJULID inget dlu awal psbb sepi } \\
\text { bgt }\end{array}$ & [inget, dilu, psbb, sepi, bgt] \\
\hline$\ldots$ & \\
\hline $\begin{array}{r}\text { Karena emang aku } \\
\text { doz }\end{array}$ & $\begin{array}{r}\text { [emang, rumah, doang, klo, bener, } \\
\text { ya, sih, han... }\end{array}$ \\
\hline @emichaelyuan_durung meneh psbb... & [durung, teh, psbb, ] \\
\hline $\begin{array}{l}\text { Ngga Gue ga bosen be } \\
\text { rumah. }\end{array}$ & $\begin{array}{l}\text { [ngga, gue, ga, bosen, bulan, } \\
\text { rumah, gue, ga, ... }\end{array}$ \\
\hline $\begin{array}{l}\text { (edewahoya pasar maling ga peduli } \\
\qquad \text { psbb ppkm, tu... }\end{array}$ & $\begin{array}{r}\text { tpasar, maling, ga, peduli, psbb, } \\
\text { ppkm, tutup,... }\end{array}$ \\
\hline $\begin{array}{c}\text { Dari awal psbb masyarakat dah punyaaa } \\
\text { trust is }\end{array}$ & $\begin{array}{r}\text { [psbb, masyarakat, dah, punyaaa, } \\
\text { trust, issue, }\end{array}$ \\
\hline
\end{tabular}

3. Tokenisasi

Gambar 5 Stemming

Tokenisasi adalah proses pemotongan seluruh urutan karakter menjadi satu potongan kata. Proses ini untuk membagi teks yang dapat berupa kalimat, paragraf atau dokumen, menjadi token-token.

\begin{tabular}{|c|c|}
\hline text & Tweet_Clean \\
\hline $\begin{array}{l}\text { Qerkytwelve @muchhilalir19 } \\
\text { QAREAJULID Pemain PS }\end{array}$ & $\begin{array}{r}\text { [main, psbb, rangkap, jd, anak } \\
\text { gawang, ppkm] }\end{array}$ \\
\hline $\begin{array}{c}\text { Lagi ngebayangin istilah PSBB, PPKM } \\
\text { masuk ke m. }\end{array}$ & $\begin{array}{r}\text { [ngebayangin, istilah, psbb, pokm, } \\
\text { masuk, mate... }\end{array}$ \\
\hline $\begin{array}{c}\text { psbb diperpanjangnya per } 2 \text { minggu, } \\
\text { skrng ppkm d. }\end{array}$ & $\begin{array}{l}\text { [psbb, panjang minggu, sking. } \\
\text { ppkm, panjang,... }\end{array}$ \\
\hline Selamat tahun baru islamirn 1 muharram & $\begin{array}{l}\text { [selamat, islam, muharram, } \mathrm{h}, \\
\text { malam, suro, doa... }\end{array}$ \\
\hline $\begin{array}{r}\text { @AREAJULID inget dlu awal psbb sepi } \\
\text { bgt }\end{array}$ & [inget, dilu, psbb, sepi, bg1] \\
\hline & $\ldots$ \\
\hline $\begin{array}{l}\text { Karena emang aku cuma di rumah } \\
\text { doang, keluar } k \text {. }\end{array}$ & $\begin{array}{r}\text { [ermang, rumah, doang, klo, bener, } \\
\text { ya, sih, han... }\end{array}$ \\
\hline @michaelyuan_durung meneh psbb. & [durung, teh, psbb,] \\
\hline $\begin{array}{l}\text { Ngga. Gue ga bosen berbulan2 di } \\
\text { rumah. Gue ga }\end{array}$ & $\begin{array}{l}\text { [ngga, gue, ga, bosen, bulan, } \\
\text { rumah, gue, ga, ... }\end{array}$ \\
\hline $\begin{array}{l}\text { @dewahoya pasar maling ga peduli } \\
\text { psbb ppkm, tu. }\end{array}$ & $\begin{array}{r}\text { [pasar, maling, ga, peduli, psbb, } \\
\text { ppkm, tutup } . . .\end{array}$ \\
\hline $\begin{array}{c}\text { Dari awal psbb masyarakat dah punyaaa } \\
\text { trust is }\end{array}$ & $\begin{array}{l}\text { [psbb, masyarakat, dah, punyaaa, } \\
\text { trust, issue, }\end{array}$ \\
\hline
\end{tabular}

4. Stopword

Gambar 6 Tokennisasi

Stopword adalah kata umum (common words) yang biasanya muncul dalam jumlah besar dan dianggap tidak memiliki makna.

\begin{tabular}{|c|c|c|c|}
\hline text & Cleansing & Remove_RT & Tweet_Clean \\
\hline $\begin{array}{l}\text { @erkywwelve @muchhilari19 } \\
\text { @AREAJULID Pemain PS... }\end{array}$ & $\begin{array}{l}\text { Pemain PSBB \&amp, merangkap jid } \\
\text { anak gavanng... }\end{array}$ & $\begin{array}{l}\text { Pemain PSBB \&amp; merangkap jd } \\
\text { anak gawang ... }\end{array}$ & $\begin{array}{r}\text { [main, psbb, rangkap, jd, anak, } \\
\text { gavang, ppkm] }\end{array}$ \\
\hline $\begin{array}{r}\text { Lagi ngebayangin istilah PSBB, PPKM } \\
\text { masuk ke m... }\end{array}$ & $\begin{array}{l}\text { Lagi ngebayyangin istliah PSBB, } \\
\text { PPKM massuk ke m... }\end{array}$ & $\begin{array}{l}\text { Lagi ngebayangnin istlah PSBB, } \\
\text { PPKM masuk ke m... }\end{array}$ & $\begin{array}{l}\text { [ngebabyangin, istliah, psbb, ppkm, } \\
\text { masuk, matte... }\end{array}$ \\
\hline $\begin{array}{l}\text { psob diperpanjanngnya per 2mingou, } \\
\text { skrng ppkm d... }\end{array}$ & $\begin{array}{l}\text { psbb diperpanjangngyya per 2minggu, } \\
\text { skmg pokm d... }\end{array}$ & $\begin{array}{l}\text { psbbo diperpanjaznonya per minggu, } \\
\text { skmg pokm di.. }\end{array}$ & $\begin{array}{l}\text { [psbbo, panjangng, minggu, skng, } \\
\text { ppkm, panjang, ... }\end{array}$ \\
\hline 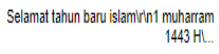 & $\begin{array}{l}\text { Selamat tahun baru islamirn' } 1 \\
\text { muharamam } 1443 \mathrm{HH} . . .\end{array}$ & $\begin{array}{l}\text { Selamat tathun banu islamirl'n } \\
\text { muharram HIrhMMa.. }\end{array}$ & $\begin{array}{l}\text { [selamat, islam, muharram, h, } \\
\text { malam, suro, doa... }\end{array}$ \\
\hline $\begin{array}{r}\text { QAREAJULID inget du aval psob sepi } \\
\text { bgt }\end{array}$ & inget dlu awal psbb sepi bgt & inget dlu aval psob sepi bgt & [inget, dlu, psbb, sepi, bgt] \\
\hline
\end{tabular}

\subsection{K-fold Cross Validation}

Setelah prosedur pre-processing pada data, langkah selanjutnya adalah pengujian terhadap analisis sentiment yang ada. Pada tahap ini diterapkan sejumlah algoritma. Gambar 4.3 menunjukkan isi dari operator "Cross Validation" pada aplikasi Rapidminer. Pada penelitian ini digunakan tiga algoritma perbandingan yaitu algoritma Decision Tree, Naïve Bayes, dan K-NN. 


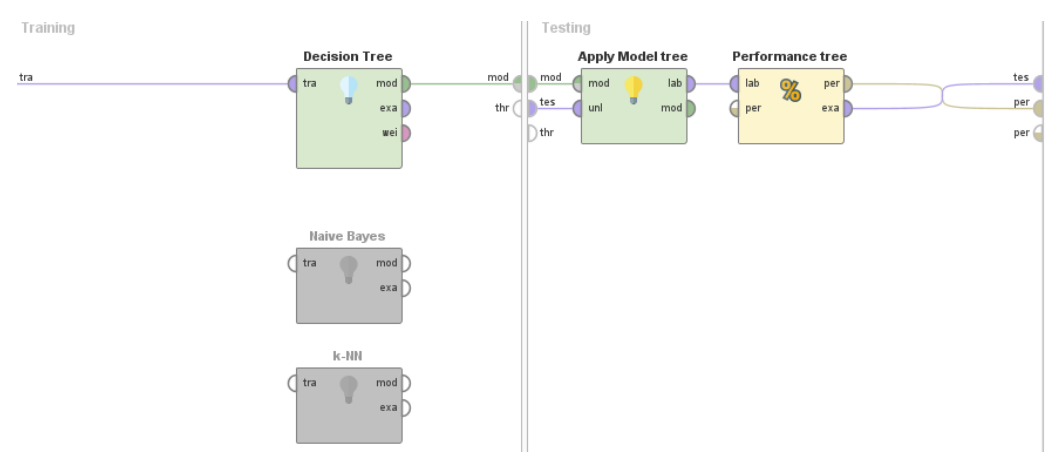

Gambar 8 Cross Validation

Setelah proses klasifikasi analisis sentimen telah selesai, langkah selanjutnya adalah mengevaluasi dengan mengukur keakurasian dan kualitas dari hasil tersebut. Evaluasi yang dilakukan adalah dengan pengujian performa dan akurasi sehingga menghasilkan nilai accuracy, precision, dan recall.

Accuracy (A) adalah total nilai True Positif dan True Negatif dibagi dengan jumlah keseluruhan data.

Precision $(\mathrm{P})$ adalah prosentase nilai True Positif dari seluruh nilai Positif yang diprediksi.

Recall (R) adalah persentase prediksi Positif dibandingkan dengan True Positif.

Berikut ini hasil yang didapat setelah melakukan penelitian dengan ketiga algoritma klasifikasi antara lain algoritma Decision Tree, Naive Bayes dan K-NN

Tabel 1 Algoritma Decision Tree

\begin{tabular}{llll}
\hline & true Positif & true Negatif & class precision \\
\hline pred. Positif & 0 & 0 & $0.00 \%$ \\
\hline pred. Negatif & 297 & 1654 & $84.78 \%$ \\
\hline class recall & $0.00 \%$ & $100.00 \%$ & \\
\hline
\end{tabular}

\begin{tabular}{llll}
\multicolumn{3}{c}{ Tabel 2 Algoritma Naïve Bayes } \\
\hline & true Positif & true Negatif & class precision \\
\hline pred. Positif & 0 & 1 & $0.00 \%$ \\
\hline pred. Negatif & 297 & 1653 & $84.77 \%$ \\
\hline class recall & $0.00 \%$ & $99.94 \%$ & \\
\hline
\end{tabular}

Tabel 3 Algoritma K-NN

\begin{tabular}{llll}
\hline & true Positif & true Negatif & class precision \\
\hline pred. Positif & 29 & 166 & $14.87 \%$ \\
\hline pred. Negatif & 268 & 1488 & $84.74 \%$ \\
\hline class recall & $9.76 \%$ & $89.96 \%$ & \\
\hline
\end{tabular}

Hasil yang didapat secara berturut untuk nilai akurasi algoritma Decision Tree, Naive Bayes dan K-NN adalah 84.78\%, 84.73\% dan $77.75 \%$. Hasil untuk nilai presisi untuk ketiga algoritma tersebut berturut-turut adalah 84.78\%, 84.77\%, dan 84.74\%. Hasil nilai recall dari ketiga algoritma tersebut adalah 100\%, 99.94\%, dan 90.00\%. Dapat dilihat bahwa algoritma Decision Tree memberikan hasil akurasi, presisi dan recall yang lebih baik untuk jenis dataset sosial media twitter dibandingkan algoritma Naive Bayes dan K-NN.

\section{KeSimpUlan}

Pada penelitian ini telah dilakukan analisis sentimen yang didapat dari tweet "PSBB" maka disimpulkan bahwa :

1. Penggunaan Decision Tree disertai dengan penggunaan teknik Cross Validation setelah membandingkan 2 algoritma lain menghasilkan hasil terbaik.

2. Berdasarkan hasil pengujian Decision Tree didapatkan hasil akurasi, presisi dan recall sebesar $84.78 \%, 84.78 \%$, dan $100 \%$. Setelah melakukan penelitian ini, untuk analisis sentimen dari tweet "PSBB" di twitter diharapkan dapat menggunakan jumlah data yang lebih besar serta dapat diuji coba dengan dataset dari media sosial lainnya untuk membuktikan lebih lanjut bahwa algoritma ini cukup baik dalam memberikan klasifikasi analisis sentiment dengan dataset dari media sosial. Algoritma yang digunakan pada penelitian ini dapat dipertimbangkan untuk diterapkan pada kasus klasifikasi teks lainnya dengan tujuan pengambilan keputusan, kebijakan publik, dsb.

\section{DAFtar Pustaka}

[1] Efid Dwi Agustono1, Daniel Sianturi2, Andi Taufik3, W. G. (2020) 'ANALISIS SENTIMEN TERHADAP WARGA CHINA SAAT PANDEMI DENGANALGORITMATERM FREQUENCY-INVERSE DOCUMENT FREQUENCY DAN SUPPORT VECTOR MACHINE', 3(2).

[2] Hanafi, I. and Ferdiansyah, R. (2020) 'SENTIMEN ANALISIS TWITTER PADA HASTAG PSBB DI INDONESIA DALAM MENGHADAPI PANDEMI COVID-19', 1(3), pp. 1011-1022.

[3] Muhammad Fadli Asshiddiqi1, K. M. L. (2020) 'Perbandingan Metode Decision Tree dan Support Vector Machine untuk Analisis Sentimen pada Instagram doi: https://doi.org/10.37859/coscitech.v2i2.2851 
Mengenai Kinerja PSSI', 7(3), pp. 9936-9948.

[4] Nengsih, W. (2017) 'Entropy Reduction Analysis dalam Penentuan Pohon Keputusan untuk Klasifikasi Data Carry Over', Entropy (p1, p2,... pn), (September 2015). Available at: http://www.academia.edu/download/39367987/ABEC2015_WarniaNengsih.pdf.

[5] Oktanisa, I. and Supianto, A. A. (2018) 'Perbandingan Teknik Klasifikasi Dalam Data Mining Untuk Bank a Comparison of Classification Techniques in Data Mining for', Teknologi Informasi dan Ilmu Komputer, 5(5), pp. 567-576. doi: 10.25126/jtiik20185958.

[6] Pangestu, A. (2020) 'Application Based of E-Commerce Poverty Prediction Data Processing', 6(2), pp. 1729-1740.

[7] Puspita, R. and Widodo, A. (2021) 'Perbandingan Metode KNN, Decision Tree, dan Naïve Bayes Terhadap Analisis Sentimen Pengguna Layanan BPJS', Jurnal Informatika Universitas Pamulang, 5(4), p. 646. doi: 10.32493/informatika.v5i4.7622.

[8] Romadloni, N. T., Santoso, I. and Budilaksono, S. (2019) 'Perbandingan Metode Naive Bayes, Knn Dan Decision Tree Terhadap Analisis Sentimen Transportasi Krl', Jurnal IKRA-ITH Informatika, 3(2), pp. 1-9.

[9] Samsir et al. (2021) 'Analisis Sentimen Pembelajaran Daring Pada Twitter di Masa Pandemi COVID-19 Menggunakan Metode Naïve Bayes', Jurnal Media Informatika Budidarma, 5, pp. 157-163. doi: 10.30865/mib.v5i1.2604.

[10] Saputra, I. et al. (2020) 'Sentiment Analysis on Twitter of Psbb Effect Using Machine Learning', Jurnal Techno Nusa Mandiri, 17(2), pp. 143-150. doi: $10.33480 /$ techno.v17i2.1635.

[11] T.P, B. P. and Indah Sari, R. D. (2017) 'Penerapan Data Mining Untuk Prakiraan Cuaca Di Kota Malang Menggunakan Algoritma Iterative Dichotomiser Tree (Id3)', Jouticla, 2(2), pp. 101-108. doi: 10.30736/jti.v2i2.68. 